\title{
Migration Issues in the Age of the COVID-19 Pandemic: A Comparison Between the European Union and Association of Southeast Asian Nations
}

\author{
Robert Mikac \\ Faculty of Political Science \\ University of Zagreb \\ Zagreb, Croatia \\ ORCID 0000-0003-4568-6299
}

\author{
Ivana Cesarec \\ Faculty of Political Sciences \\ University of Zagreb \\ Zagreb, Croatia \\ ORCID 0000-0002-3533-1745
}

\author{
Ali Musa Harahap \\ Department of International \\ Relations \\ University of Darussalam Gontor \\ Ponorogo, Indonesia \\ aliemharahap@gmail.com
}

\begin{abstract}
Migration is an extremely important topic, which may arouse more or less interest, depending on the political and social context. Due to its phenomenology, comprehensiveness, importance as well as the impossibility of reducing it to the state level, the modern approach to the issue of migration must include a policy and polity analysis of the activities of international organizations. The focus of this review paper is a comparison of the actions of the European Union (EU) and Association of Southeast Asian Nations (ASEAN) towards migration issues, especially from the aspect of the situation caused by the COVID-19 pandemic. The purpose of the research is to observe the current course of activities of these two organizations and examine whether and to what extent there has been a change in their activities due to the COVID-19 pandemic. The central research question is: How does the $E U$ and ASEAN approach the issue of migration in general and during the COVID-19 pandemic in particular? The aim of the analysis is to compare approaches and identify differences in treatment between the EU and ASEAN.
\end{abstract}

Keywords-migration, COVID-19 pandemic, EU, ASEAN

\section{INTRODUCTION}

Migration means different things for individuals, countries, economies, and the world [1]. Migrations are a historical constant, they have always happened, they are happening now and the future will be marked by them. They have always been generated by push and pull factors that have affected individuals and entire groups of peoples. The most significant push factors are related to security, hunger, poverty, avoidance of war and terror. At the same time, the pull factors are characterized by the desire for a better life, the possibility of employment and study, family reunification, and economic perspective. Accordingly, numerous disciplines of migration research have been developed: Migration and Human Rights [2]; Migration and Security [3], [4]; Globalization of Migration [5]; Labor and Migration [6]; Law and Asylum [7]; Environment and Migration (natural disasters, climate change) [8], [9]. In addition to the above, there are many other disciplines of migration research. In this research, we are interested in the interdisciplinary approach of international organizations (EU and ASEAN) to migration issues.

The next important element of this research is the COVID-19 pandemic. The coronavirus disease (SARS-CoV-2) and the COVID-19 pandemic originated in China in late 2019 [10], and spread throughout the world through international travel causing immediate and immeasurable consequences. „Coronavirus and the COVID-19 pandemic have caused a unique crisis in the entire human history because it literally affected the whole world, which has never happened before" [11]. Numerous organizations and states have been forced to take radical measures to curb the pandemic, protect the population and save the economy [12]. The pandemic has highlighted a number of challenges and shortcomings around the world, such as: ,from the number of intensive-care beds to the size of the workforce, the inability to provide enough masks and to deploy testing in some countries, and deficiencies in the research for and supply of drugs and vaccines“" [13]. These developments have united the world in the 
search for a vaccine (until it is found). Still, it has also been shown that vaccines, once developed, have become a tool in geopolitical competition as a means of making big money. Likewise, the pandemic has caused some changes in the approach to migration issues, which we plan to explore later in this paper.

Globally, the number of migrants is increasing from year to year. Currently, estimates from the World Economic Forum show that there are „272 million international migrants $-3.5 \%$ of the world's population. While most people leave their home countries for work, millions have been driven away due to conflict, violence and climate change" [14]. When we look at the 2019 statistics, the first of the 25 countries that are the most desired destinations is convincingly the United States. In the top 25, there are five countries in the European Union (Germany, UK, France, Italy, Spain) and two ASEAN countries (Malaysia and Vietnam) [15]. Pew Research Center, researching global migration flows from a regional perspective between 1990 and 2017, concluded that there are three significant trends in incoming migration: from Latin America to North America; from South Asia to Europe; and from South Asia to Southwest Asia [16]. The reasons for migration are often very different, while travel is dangerous (especially for illegal migrants). There are numerous examples of exploitation of migrants, their accidents while traveling, and the devastation of not being able to reach their destination. The COVID-19 pandemic, the closure of borders, and the tightening of numerous security measures have made travel difficult for legal and illegal migrants.

The methodology of this paper is based on the research of the regional approach (EU and ASEAN) towards the issue of migration. Conceptually, we do not differentiate between legal and illegal migrations, but we are interested in the totality of approaches, especially in the circumstances of the COVID-19 pandemic. To this end, we conduct a policy analysis of available strategies and other official documents and provide insight into other sources that address this topic. The research aims to investigate the similarities and differences in approaches and activities between the two organizations.

In order to structure the research, the text will be divided into three additional sections after the Introduction. The second section, European Union, migration issues and COVID-19 pandemic, will research the EU's Key strategies and policies, EU and the Member States: implementing migration policy, and COVID-19 pandemic: challenges and approaches to migration issues. The next section entitled Association of Southeast Asian Nations, migration issues and COVID-19 pandemic will give an analysis of the current migration legislation and policies, as well as policy gaps and challenges during COVID-19. The last section, Conclusion, will provide a summary of the research and a review of the total collected material and the results of the analysis.

\section{EUROPEAN UNION, MIGRATION ISSUES AND COVID- 19 PANDEMIC}

The European Union is an intergovernmental and supranational organization of (currently) 27 European countries unified in the same goal - the economic and political integration of the European continent. The Maastricht Treaty (adopted in 1993) provided the legal basis for the creation of an organization that improves cooperation between European countries in foreign policy, internal affairs and judicial affairs (as the Three pillars of the EU). In 1997, the Treaty of Amsterdam (adopted in 1999) amended the Treaty on the European Union, the Treaties establishing the European Communities and related acts, with substantial changes to the Maastricht Treaty, also introducing provisions that allow free crossing of internal borders of EU member states, closer cooperation of individual member states and their integration. Additionally, the organizational structure of the EU was reformed with the Lisbon Treaty in 2009, removing the Three pillars and providing more efficient and democratic policy-making with the new policies and competencies, etc

Today, the European Union aims to: a) promote balanced and sustainable economic and social progress, in particular by creating areas without internal borders, strengthening economic and social cohesion and establishing an economic and monetary union with the introduction of a single currency; b) reaffirm the Union's identity on the international level, in particular through joint foreign and security policy, including the possible establishment of a common defence policy, c) strengthen and protect the rights and interests of nationals of the Member States through the introduction of Union citizenship, and d) establish close cooperation in the field of internal affairs [17]. These aims are further strengthened through principles common to all Member States - freedom, democracy, respect for human rights and fundamental freedoms, and the rule of law [18].

As it is shown, the EU is an alliance of sovereign states formed by international treaties, guided by the same aims and principles. Nevertheless, within the European Union, there are (often) significant differences between Member States on key issues, which can be challenging for the implementation of some policies such as migration policies.

Migration is not a new challenge for the EU. In the beginning of the 1990s, conflicts in the former Yugoslavia led to waves of refugees from Bosnia and Herzegovina and Croatia to the EU Member States: Germany, Great Britain and some Scandinavian countries. Also, economy was one of the "triggers" for mass labour migration to these states. Consequently, the first significant changes in European migration 
policy begun in those years. Although the first documents of the European Commission dealing with the rights of migrants appeared twenty years earlier, the fact is that they referred mainly to migrants who were citizens of other Member States and not third countries, and that they were created at a time when the EU and its Member States pursued the so-called "zero immigration policy" after the oil crisis of the 1970s. The Maastricht Treaty was the one that defined immigration as "an issue of common interest" [19]. However, it was not until the Treaty of Amsterdam that European immigration policy gained momentum and began to develop in a direction that would place an increasing emphasis on human rights and integration of third-country nationals, not just immigrants from other Member States. It stipulates that within five years of signing (1997), the Council will adopt immigration policy measures relating to entry and residence. Analyzing the migration crisis in 2015 , it has emphasized the need for greater coordination between Member States, but also the gap between the European and national levels on immigration and asylum issues [20].

In its Introduction, we can see that the EU deals with migration over 30 years, and during that period the legal framework for immigration policy and its implementation mechanisms has been established at the EU level - covering to a lesser extent the form of citizenship for third-country immigrants in its policy agenda. This is understandable since the global challenges were much different, and there was not that much influx from these countries, for example, climate changes did not have the effects they have today, wars are now more destructive and much more people search for a better (or any) life in the EU. How the strategies and policies were developed will be shown in the next few sections.

\section{A. EU Key strategies and policies}

In terms of immigration policy, we can summarize that the European Union is responsible for defining the conditions of entry and residence, defining the number of persons from third countries coming for employment and combating illegal migration, i.e. encouraging the Member States to take measures to prevent and reduce illegal migration.

The key provisions of the migration policy of the European Union (and accordingly the Member States), as well as the regulation of the Common European Asylum System, are outlined in the founding treaties which are the basis of the primary legislation of the European Union. The Maastricht Treaty (1993) placed the area of asylum and migration in Pillar III: Justice and Home Affairs. A further major step, without which it would not be possible to discuss the creation of a common policy in the field of justice and home affairs, was taken by the Treaty of Amsterdam, which introduced harmonization of the European visa system, uniform control of external borders, harmonization of asylum policy, whereby the provisions of the Schengen agreements have been incorporated into the legal system of the European Union. Thus, part of the policies that were in Pillar III moved to Pillar I (borders, asylum, migration, visa policy), whereby the Member States renounced exclusive responsibility for these areas and gave competence, i.e. the right to initiate measures to Union bodies, primarily the European Commission [21]. These were the first "steps" towards developing the EU migration policy.

In 2015, at the very beginning of the migrant crisis, it was recognized that the EU must apply concrete and direct measures (although at the time it did not have a common policy on migration management and border security) since the Member States could not deal with the migration challenge on their own. As a common European solution in May 2015, the European Commission presented a comprehensive European Migration Program to address the immediate challenges and to act as an instrument for better and longer-term management of both legal and illegal migration. The European Migration Program is based on one simple principle - provide assistance to migrants in need of international protection and return migrants to their countries of origin if they do not have the right to reside in the EU. It seeks to approach overall migration proactively, through four pillars of better migration management: 1 . by reducing incentives for illegal migration; 2 . border management - saving lives and securing external borders; 3. a strong common asylum policy; 4 . a new policy in the field of legal migration [22]. The program has partially reduced illegal crossings, and further encouraged the development of refugee assistance programs and projects in, for example, Syria and other countries of origin of migrants (as a long-term measure). For an adequate implementation of the European migration policy, it is absolutely necessary that all Member States fully implement the common rules on asylum and illegal migration agreed at the EU level. The importance of the above mentioned and the challenges that have arisen in relation to the solutions offered at the EU level will be discussed below.

Given the limited length of this research, we will not go into all EU strategies and policies that to some extent mention (cover) migration, just the European Migration Program. We can add that the European Parliament has adopted a number of resolutions on migration, in particular the Resolution of 12 April 2016 on the situation in the Mediterranean and the need for a holistic EU approach to migration (2015/2095(INI)) and on addressing refugee and migrant movements: the role of EU External Action (2015/2342(INI)). These resolutions assess relevant policies and make a number of recommendations. 


\section{B. EU and the Member States: implemening migration policy}

As stated earlier, the challenges that the EU faced with the influx of large numbers of refugees have also highlighted a number of shortcomings in EU policy on asylum, external borders and migration.

One of the first emergency measures was adopted after the 2015 migration wave and sought to alleviate migratory pressure on Greece and Italy, which were most exposed to the influx. The aim was to relocate eligible applicants for international protection to other Member States to ensure a fair and balanced distribution of migrants and sharing of responsibilities for asylum seekers in the EU (a quota system whereby each member would accept a certain number of refugees). However, not all Member States (such as the Visegrad Group countries) were willing to participate in the program, which showed a difference of opinion and a difficulty in striking a balance between responsibilities between different EU Member States. As has been shown, in the event of a major migration crisis, Member States tend to focus on their particular interests and "ignore" joint action, and this has been proven on several occasions [23].

At the same time, the European Union tried to establish partnerships with neighbouring countries (e.g., Turkey) in order to reduce the burden of migrant flows, which did not prove to be very purposeful, so the Union sought the solution in the implementation of numerous security mechanisms, such as border demarcation and operations against migrant smugglers - which cannot provide a sustainable solution [24].

The basis for a more successful implementation of EU migration policy certainly lies in the cooperation between Member States. It is clear that there are differences in geography, history, culture, attitudes towards migrants, interdependence with non-EU countries, and financial differences due to which Member States have different roles and involvement in asylum and migration policy implementation. In addition, it is difficult to "impose" cooperation among EU Member States on migration-related policies in order to implement them in all countries - it has been proved ineffective in the past and will certainly not be much more successful in the future unless coordinated actions are designed by the European Commission that have in mind the specificities of Member States and facilitate implementation (e.g. funding, etc.).

\section{COVID-19 pandemic: challenges and approaches to migration issues}

The highest ever influx of migrants to Europe during 2015 and 2016 weakened by the end of 2017 and 2018. However, in order to strengthen EU migration policy, current and long-term measures continued to be implemented - as irregular migration is one of the important parts of the EU's political agenda. Year 2019 brought a completely new challenge that only exacerbated the governance crisis - COVID-19. Although the migrant crisis affected some EU countries to a greater extent than others, the COVID-19 pandemic affected absolutely the entire world. The "fear" of the spread of disease that countries have shown towards European neighbouring countries has further increased with the threat of irregular migrants from third countries (seen as spreaders of the virus), that resulted in even more restrictive migration measures. Some of them are related to migration controls, for example, Italy has adopted a decree/guideline concerning access to relief or international protection [25] by closing their ports to persons rescued at sea.

The WHO declared COVID-19 a global pandemic on 11 March 2020 and while the most invasive COVID-19 measures have been implemented within EU Member States, such as lockdown, closure of businesses etc., the cross-border aspects (restrictions on cross border movement) have been important [26]. For example, internal border controls within the Schengen Area were reintroduced to prevent irregular secondary movements of migrants from neighbouring countries. The COVID-19 pandemic has challenged our perception of mobility and how we can "move" worldwide. It is estimated that at least 194 countries have implemented mobility restrictions as a response to COVID-19 [27]. Although countries have a "legitimate right" to close borders for health (pandemic) reasons, the question arises as to whether individual governments use COVID-19 as a "justification" for more rigorous border closures to address migration, especially as they are obliged to grant asylum access to those seeking protection (although the EC has clearly urged Member States to maintain the right to asylum even in a pandemic). Therefore, many refugees are at increased risk in terms of safety.

It can be perceived that the COVID-19 pandemic has substantially reduced the number of irregular arrivals to the EU. In April 2020, the number of detections of irregular border crossings on Europe's main migratory routes fell by 85 per cent from the previous month to around 900, the lowest total since Frontex began collecting border data in 2009 [28]. The European Commission survey on asylum and irregular border crossings also confirms the impact of the pandemic on migration to the EU in 10 months of 2020 - The EU as a whole registered a 33\% year-onyear decrease in asylum applications and a 6-year low in irregular border crossings. However, the overall number of arrivals has continued to grow after a large drop around April 2020 [29].

COVID-19 has "confirmed" a global interconnectedness. Also, we realized that migration issues should be perceived from different angles - we have legal migrant workers that are currently working on jobs that "everyone are afraid to do" due to the 
pandemic, or some of them cannot access their jobs in other countries (which has consequences on their families and national economies). On the other hand, we are dealing with issues of millions of refugees living in unsanitary conditions in camps and urban settings without humanitarian support. Specifically, three quarters of the world's refugees and a large number of migrants are located in developing regions where health systems are already overburdened and have insufficient capacity. Many of them live in overcrowded camps, settlements, makeshift shelters or reception centers, where they do not have adequate access to health services, clean water and sanitation [30].

There is an awareness that receiving a large number of irregular migrants and asylum seekers is challenging during the COVID-19 pandemic and presents a great public health risk due to their inability to access health care, lack of proper registration to be able to track who could be the transmitter of the virus, etc. Irregular immigrants, including those seeking to apply for asylum, are not covered by international cooperation for infectious disease control and prevention. While it is considered good practice in international migration policy to work to reduce irregular migration, the pandemic in no way obviates the right of refugees to humane reception conditions and protection [31]. Refugee protection should be raised not only having in mind a basic humanitarian requirement, but also for the purposes of reducing the risk of COVID-19 spreading. Also, these requirements are in most cases not part of national or EU policies. According to the research conducted by the Red Cross, even in situations where migrants had been included in COVID-19 policies, their actual ability to access basic services was often constrained. For example, in some countries, migrants have been unable to access COVID-19 testing or treatment because they do not have a national identity or social security number. This is also likely to affect access to COVID-19 vaccinations, even if eligibility legally exists [32]. If the pandemic maintains its global impact (but also for all future potential health crises), it is necessary to include in policies those who are or want to become new members of the European community - because it is clear that migration is something that greatly marks today's global society.

\section{Summary of achievements, open issues and challenges}

As it was to some extent presented in this research, the crisis caused by the COVID-19 pandemic, same as the 2015 migrant crisis, showed a similar "response" EU member states are guided more by national interests than by common ones. The lack of unity and solidarity with regard to migrants has been exacerbated by the pandemic. This can be seen as a direct consequence of ineffective European migration policy despite efforts in its development, but also in general, the crisis of governance and a belated reaction of the EU, which has "left" the Member States to deal with the health crisis on their own. Some did it less and some more successfully. Currently, as in the case of the migrant crisis, ad hoc solutions and measures have been used to mitigate the "burning" issues.

The Commission has published several Guidelines and Communications trying to give Member States general "instructions". In one of them, it specifies that: "Measures taken by Member States to contain and limit the further spread of COVID-19 should be based on risk assessments and scientific advice and must remain proportionate. Any restrictions in the field of asylum return and resettlement must be proportional, implemented in a non-discriminatory way and take into account the principle of non-refoulement and obligations under international law" [33]. From a humanitarian point of view, as well as public health, the EU has ultimately taken certain "steps" at the strategic level, and again, it depends on the Member States to implement these recommendations.

We could have presumed (following the trends from the first wave of migrants in 2015) that the EU would also face the challenge of a growing influx of migrants in 2019. Consequently, the emergence of the pandemic, with the implementation of lockdown measures in EU Member States, influenced flows of both illegal and legal migration. Due to the prevention of spreading of COVID-19, activities of law enforcement institutions in the Member States restricted the movement not only of their citizens but also of everyone else. That did not stop illegal migration altogether, but influenced the ability of migrants to reach planned destinations or, for example, afford to pay smugglers, whose prices have increased due to COVID-19 restrictions. Therefore, their independent travel increases risks of various difficulties on their way (e.g., deadly outcome, etc.). Migrants are still organized and, assuming that some of them will reach their target destinations or countries in transit, EU Member States should have border measures in place, such as quarantine requirements, on-the-spot testing and the like, so that virus carriers could be identified and addressed accordingly. EU Member States should also share responsibility for refugee protection having in mind the general aims and principles of the EU, but also cooperate with nonEU countries that are a part of migrant routes (e.g. Balkan route)

\section{ASSOCIATION OF SOUTHEAST ASIAN NATIONS,} MIGRATION ISSUES AND THE COVID-19 PANDEMIC

First of all, ASEAN stands for the Association of Southeast Asian Nations or when translated in Indonesia, the United Nations of Asia Southeast. ASEAN was founded on 8th August 1967 in Bangkok, through the signing of the Bangkok Declaration („Bangkok Declaration“), or often called „ASEAN Declaration", by Indonesia, Singapore, Malaysia, 
Thailand and the Philippines [34]. This organization aims to increase friendship and cooperation in the areas of economic growth, social progress and development of the cultures of the member countries. With regard to the background of various ASEAN member countries, forms of cooperation there must be based on common factors so that ASEAN can develop into an effective regional international organization.

Basically, the purpose of formation of ASEAN was to create a region of Southeast Asia in an atmosphere of friendship, prosperity and peace. More importantly, in a political sense, ASEAN affirms itself as an organization that respects and is determined to uphold human rights (HAM) and democratic values. This is in accordance with the contents of the Bangkok Declaration, among others:

1) "to accelerate the economic growth, social progress and cultural development in the region through joint endeavours in the spirit of equality and partnership in order to strengthen the foundation for a prosperous and peaceful community of Southeast Asian nations;

2) to promote regional peace and stability through abiding respect for justice and the rule of law in the relationship among countries in the region and adherence to the principles of the United Nations Charter;

3) to promote active collaboration and mutual assistance on matters of common interest in the economic, social, cultural, technical, scientific and administrative fields;" and

4) "the Association represents the collective will of the nations of Southeast Asia to bind themselves together in friendship and cooperation and, through joint efforts and sacrifices, secure for their peoples and for posterity the blessings of peace, freedom and prosperity" [35].

\section{A. Current legislation and policies: migration}

Admittedly, though ASEAN leaders spoke expressively about mutual trade and investment at almost all of their summits, they discussed little about another important regional flow: migration. Their primary focus is still foreign direct investment, international merchandise trade, macroeconomic, international trade in services and transport, and the labor sector. With regard to migration policies, ASEAN formulates their commitment to assist migration policy under the framework of 'protection and migration policy'. However, the primary focus is still on migrant labour force only [36]. Little attention is given to other various type of migration such as pandemic and irregular migration or forced migration. They largely ignored much larger movements of other groups of people who cross state boundaries on a regular basis, often in search of a better life.
Migration is a major political factor in the region, with a clear divide between countries that primarily supply migrant labour force, such as Cambodia, Indonesia, Myanmar, the Philippines, and Vietnam, and those that receive it, such as Thailand, Malaysia, and Singapore. This region also faced the issue of Rohingya refugees [37]. However, ASEAN may have a response toward COVID-19 with its external relations, the European Union. With a more narrative commitment, in the battle against the COVID-19 pandemic, ASEAN promised to continue to take joint action and coordinate policies, including with its partners. On 20th March 2020, an ASEAN-EU Ministerial Video Conference on COVID-19 was held, with both sides agreeing to increase cooperation within ASEAN-led frameworks as well as with external partners to resolve COVID-19 in a comprehensive manner, taking into account the various levels of growth of health systems in the country [38].

\section{B. Policy gaps and challenges during the Covid 19- pandemic}

ASEAN member countries have different migration management strategies as ASEAN does not have a common blueprint to respond to migration issues. Before and during the COVID-19 pandemic today, the issues of migration are present. Member countries are not coordinated enough to assist migrant groups. As a result, each of them fell victim to their own mistakes, for instance, Indonesia. Despite laws and regulations, exploitation during the working cycle in destination countries, as well as during the recruitment process in the home country and repatriation, is one of the most problematic aspects of the growth of Indonesian migrant workers working abroad as domestic workers. Although there are some success stories, these female migrants are clearly at a disadvantage. Workers are exposed to a wide range of risks, including exploitation and prejudice. There are no national legal instruments that protect female migrant workers, and the Indonesian government has not committed to ratifying foreign legal instruments that protect migrant workers [39].

Myanmar shares similar experiences. Migrants are subjected to a cycle of detention, extortion, trafficking, debt bondage, and deportation at border crossings. In Philippines, many cases have shown that the social laws of the states provide limited assistance and protection to migrant groups. In Malaysia, there is a shift from a unilateral to a bilateral approach to migrant groups such as migrant workers. As a result, the Malaysian government has no capacity to control and protect migrants irrespective of their status and jobs [39].

For an institution such as ASEAN, developing common policies on issues like migration is challenging, this paper argues. The humanitarian aspects of migration should be addressed by ASEAN- 
wide agreements. A common European Union framework for the human rights of migrants should prevail. As a region, ASEAN needs to empower rules and regulations with real policy implementation. Routine evaluation should be conducted from time to time. In addition, protocols for dealing with crossborder communicable diseases, refugees, and forced migrants must be developed in the area. Political will of all member countries must be present and wellcoordinated in order for ASEAN to maintain its collective policy goals and objectives: protecting migrants. The COVID-19 pandemic is no doubt disrupting migration throughout the ASEAN region and globally, but dismantling the issue with common good-will, framework and a humanistic approach could minimize the consequences of such a calamity.

\section{CONCLUSION}

The research showed that two organizations - the EU and ASEAN - have a long tradition concerning migration issues. These organizations have a long history of dealing with the challenges of migration because they are environments that have migrations within member states and inbound migrations from other regions of the world. The solutions implemented by organizations are somewhat different, since the EU has more mechanisms at its disposal than ASEAN. In contrast, both organizations seek to work intensively with all Member States on migration. Interestingly, there is a dialogue between the EU and ASEAN on many issues, including migration.

Regarding the central question: How does the EU and ASEAN approach the issue of migration in general and during the COVID-19 pandemic in particular?, the research showed that both organizations face significant challenges in harmonizing public policies on migration, which were further complicated during the COVID-19 pandemic. The already very uncertain and lengthy bilateral process related to migration (on the one hand, the analyzed organizations and their member states, and on the other hand, migrants) has become even more demanding and challenging under the influence of the COVID-19 pandemic

The research showed that the EU and ASEAN have a positive attitude towards migration issues, but implementing policies is a challenge and a problem partly because the implementation depends on cooperation between organizations and member states. There are some solutions on both sides that are being implemented, and it would be helpful for them to work together more to share examples of good practice. We would like to emphasize this at the end of this research, as it is necessary to increase cooperation between different actors and organizations related to the issue of migration in general, and especially during the COVID-19 pandemic.

\section{REFERENCES}

[1] World101, "What is Migration? Global Era Issues", 2021 https://world101.cfr.org/global-era-issues/migration/whatmigration

[2] International Organization for Migration, "The Human Rights of Migrants", International Migration Vol. 38 (6) Special Issue $3 / 2000,2000$,

https://publications.iom.int/system/files/pdf/migrants_human_r ights.pdf

[3] E. Guild, J. Selm, "International Migration and Security: Opportunities and Challenges", London: Routledge, 2005.

[4] W. Walters, "Migration and Security" in: Burgess P (ed.) The Routledge Handbook of New Security Studies, London: Routledge, 2010.

[5] M. Mesić, "Globalization of migration (Croatian: Globalizacija migracija)", Zagreb: Journal of Migration and ethnic issues, 2002, Vol. 18, No. 1, pp. 7-22, https://hrcak.srce.hr/file/158214

[6] D. Bartram, "International Labour Migration: Foreign Workers and Public Policy", London: Palgrave Macmillan, 2005.

[7] S. Behrman, "Law and Asylum: Space, Subject, Resistance", London: Routledge, 2018.

[8] A. Drabo, L. Mously Mbaye, "Natural disasters, migration and education: an empirical analysis in developing countries", Cambridge: Cambridge University Press, 2014.

[9] A. Ginty, "Climate Change Solutions and Environmental Migration: The Injustice of Maladaptation and the Gendered 'Silent Offset' Economy”, London: Routledge, 2021.

[10] World Health Organization, "WHO-convened global study of origins of SARS-CoV-2: China Part", Joint WHO-China study: 14 January - 10 February 2021, 2021, https://www.who.int/docs/default-source/coronaviruse/finaljoint-report_origins-studies-6-april201.pdf?sfvrsn=4f5e5196_1\&download=true

[11] R. Mikac, "Covid-19 Pandemic and Crisis Management in the Republic of Croatia". Zagreb: Journal Anali, Vol. 17, No. 1, pp 31-55, 2020, https://hrcak.srce.hr/file/359617

[12] World Bank, "Global Economic Prospects (January 2021)", A World Bank Group Flagship Report, 2021, https://openknowledge.worldbank.org/bitstream/handle/10986/ 34710/9781464816123.pdf

[13] A. Gurria, "Coronavirus (COVID-19): Joint actions to win the war". Organisation for Economic Co-operation and Development, 2020, https://www.oecd.org/about/secretarygeneral/Coronavirus-COVID-19-Joint-actions-to-win-thewar.pdf

[14] C. Edmond, "Global migration, by the numbers: who migrates, where they go and why", World Economic Forum, 2020, https://www.weforum.org/agenda/2020/01/iom-globalmigration-report-international-migrants-2020/

[15] Migration Policy Institute, “Top 25 Destinations of International Migrants, 2019, https://www.migrationpolicy.org/programs/datahub/charts/top-25-destinations-international-migrants

[16] Pew Research Center, "Orgins and Destinations of the World's Migrants, 1990-2017”, 2018, https://www.pewresearch.org/global/interactives/globalmigrant-stocks-map/

[17] Croatian Encyclopaedia," European Union”, Online Edition Miroslav Krleža Institute of Lexicography, 2021, https://www.enciklopedija.hr/Natuknica.aspx?ID=18657

[18] European Union, “The EU in brief", 2021, https://europa.eu/european-union/about-eu/eu-in-brief_en

[19] B. Perchinig, "EU Citizenship and the Status of Third Country Nationals" in: Bauböck, R (ed.) Migration and Citizenship: Legal Status, Rights and Political Participation. Amsterdam Amsterdam University Press, 2006 
[20] N. Popović, "European Union immigration policy on the refugee crisis test". Zagreb: Political Analysis, 2015, Vol. 6 , No. 23, pp. 30-35, https://hrcak.srce.hr/151264

[21] F. Dragović, R. Mikac, "Creating security policies of the European Union”, Police and Security, 2011, vol. 21, No. 1 , pp. 22-48, https://hrcak.srce.hr/84273

[22] European Commission, "Communication from the Commission to the European Parliament, the Council, the European Economic and Social Committee and the Committee of the Regions: A European Agenda on Migration", 2015, https://ec.europa.eu/antitrafficking/sites/antitrafficking/files/communication_on_the_eu ropean_agenda_on_migration_en.pdf

[23] R. Mikac, I.Cesarec, K. Jajić, "Migration policies of the European Union and Australia: similarities and differences", International Studies, 2016, Vol. 16, No. 1, pp 85-103, https://hrcak.srce.hr/187874

[24] A. Dimitriadi, "Deals without borders: Europe's foreign policy on migration", London: European Council on Foreign Relations, 2016, https://www.files.ethz.ch/isn/196757/ECFR165-DEALS_WITHOUT_BORDERS.pdf

[25] L. Tondo, "Italy declares own ports 'unsafe' to stop migrants arriving", Palermo: The Guardian, 2020, https://www.theguardian.com/world/2020/apr/08/italydeclares-own-ports-unsafe-to-stop-migrants-disembarking

[26] E. Guild, "Covid-19 Using Border Controls to Fight a Pandemic? Reflections From the European Union”, Frontiers in Human Dynanics, 2020, https://www.frontiersin.org/articles/10.3389/fhumd.2020.6062 99/full

[27] International Organization for Migration, "Global Mobility Restriction Overview", 2020,

https://migration.iom.int/system/tdf/reports/DTM-

COVID19\%20Global\%20Overview\%20Output\%2010.05.2021

$\%$ 20FINAL.pdf?file $=1 \&$ type $=$ node $\&$ id $=11452$

[28] Frontex, "Situation at EU external borders in April Detections lowest since 2009", 2020, https://frontex.europa.eu/media-centre/news/newsrelease/situation-at-eu-external-borders-in-april-detectionslowest-since-2009-mJE5Uv

[29] European Commission, "Statistics on migration to Europe", 2021, https://ec.europa.eu/info/strategy/priorities-20192024/promoting-our-european-way-life/statistics-migrationeurope_en\#the-atlas-on-migration
[30] S. Roksandić, K. Mamić, R. Mikac, "Migration in the Time of COVID-19: Policy Responses and Practices in Croatia Concerning the Western Balkan Routes and Readiness for the Post-COVID-19 Society in Which the Right to Health Care for the Most Vulnerable Is Guaranteed", Frontiers in Human Dynanics, 2021, https://www.frontiersin.org/articles/10.3389/fhumd.2021.5951 89/full

[31] M. Lücke, "COVID-19 Impact on International Migration: Upheaval in the Short Run, but Few Lasting Effects", Kiel Institute for the World Economy, 2020, No. 26, page 56-64.

[32] Red Cross EU Office, "New Report: Migrants hit an 'Invisible Wall' in accessing COVID-19 care nad vaccines", 2021, https://redcross.eu/latest-news/new-report-migrants-hit-aninvisible-wall-in-accessing-covid-19-care-and-vaccines

[33] European Commission, "COMMUNICATION FROM THE COMMISSION COVID-19: Guidance on the implementation of relevant EU provisions in the area of asylum and return procedures and on resettlement", 2020, https://www.refworld.org/docid/5e99707d4.html

[34] AK. Syahmin SH, "Actual Problems of International Organization Law”, Bandung, CV. ARMICO, 1988.

[35] ASEAN, "Bangkok Declaration", 1967, https://agreement.asean.org/media/download/20140117154159 .pdf

[36] ASEAN, "ASEAN Consensus on the Protection and Promotion of the Rights of Migrant Workers", 2021, https://asean.org/wp-content/uploads/2012/05/16-ASEANDeclaration-on-the-Protection-and-Promotion-of-the-Rightsof-Mi....pdf

[37] M. Tuccio, "Determinants of Intra-ASEAN Migration. Asian Development Review", 2017, vol. 34, no. 1.

[38] ASEAN, "Co-Chairs' Press Statement ASEAN-EU Ministerial Video Conference on the Coronavirus Disease 2019", 2020, https://asean.org/co-chairs-press-statement-asean-euministerial-video-conference-on-the-coronavirus-disease-20192/

[39] Basir, Salawati Mat, "Irregular Migrations in Southeast Asia: Challenges for Protection and Migration Policy", Indonesian Journal of International Law, 2020, Vol. 17, No. 2. 